\title{
Впровадження австралійських класифікаторів для кодування пролікованих у стаціонарі випадків в Україні: який підхід виявився найбілыш ефективним
}

\author{
${ }^{1}$ Національний медичний університет ім. О.О. Богомольця, м. Київ, Україна \\ ${ }^{2}$ ДУ «Національний науковий центр «Інститут кардіології ім. акад. М.Д. Стражеска» НАМН України, м. Київ, Україна \\ ${ }^{3}$ ДУ «Національний інститут серцево-судинної хірургії ім. М.М. Амосова НАМН України», м. Київ, Україна \\ imogilevkina@gmail.com, annadoroxina@ukr.net, newsersir@gmail.com
}

\author{
Могилевкина И.А., Дорохина А.Н., Сиромаха С.О. \\ Внедрение австралийских классификаторов \\ для кодирования пролеченных в стационаре случаев \\ в Украине: какой подход оказался \\ наиболее эффективным
}

\author{
Mogilevkina I.O., Dorokhina A.M., Siromakha S.O. \\ Implementation of Australian Classifiers \\ for inpatient coding in Ukraine: \\ which approach proved to be the most effective
}

\section{Вступ}

Програма медичних гарантій, яка стартувала в Україні $з 1$ квітня 2020 року, передбачає зміну оплати діяльності стаціонарів залежно від пролікованих випадків. I навіть якщо на першому етапі оплата проводиться лише за пріоритетними напрямками та, насправді, не відображає реальних витрат стаціонарів на надання медичної допомоги, в подальшому, вона має бути чітко прив'язана до визначеної діагностично-спорідненої групи.

321 грудня 2019 року в країні відповідно до наказу Мінекономіки від 13 грудня 2019 року №677 «Про затвердження національних класифікаторів» (1) затверджено застосування НК 025:2019 - Класифікатора хвороб та споріднених проблем охорони здоров'я (2) та НК 026:2019 - Класифікатора медичних інтервенцій (3).

Національні класифікатори гармонізовано 3 Австралійським класифікатором хвороб - The International Statistical Classification of Diseases and Related Health Problems, Tenth Revision, Australian Modification, ICD-10AM 2017 (4) та Австралійським класифікатором медичних інтервенцій (Australian Classification of Health Interventions, ACHI, 2017) (5).

Пілотування Австралійських класифікаторів розпочалось в Україні з липня 2019 року в межах проекту «Пілотне впровадження системи ДСГ (на основі австралійської системи ДСГ) на рівні МОЗ та вибраних медичних закладів (навчання, програмне забезпечення тощо)» (спільний зі Світовим Банком проект МОЗ України «Поліпшення охорони здоров'я на службі у людей») (6).

Мета - проаналізувати відмінності Австралійського класифікатора медичних інтервенцій (АКМІ, 2017) та НК 026:2019 - «Класифікатора медичних інтервенцій» від Тимчасового галузевого класифікатору медичних процедур (послуг) та хірургічних операцій, затвердженого наказом МО3 України від 14.02.2007 p. № 67 (7), визначити найбільш ефективну, з точки зору коректності кодування, модель впровадження кодування за австралійським класифікаторами в межах пілотного проекту, розробити кроки щодо усунення найбільш частих помилок при використанні австралійського класифікатора медичних інтервенцій під час кодування випадків стаціонарного лікування в закладах охорони здоров'я.

\section{Матеріали та методи}

Відмінності Австралійського класифікатора медичних інтервенцій (АКМІ, 2017) та НК 026:2019 «Класифікатора медичних інтервенцій» від Тимчасового галузевого класифікатора медичних процедур (послуг) та хірургічних операцій, затвердженого наказом MO3 України від 14.02.2007 р. № 67.

30552 випадки стаціонарного лікування, що внесені в електронну систему Українських діагностичноспоріднених груп (УДСГ, UDRG) протягом липня-грудня 2019 року в 3 пілотних лікарнях. Під час монітрингових візитів авторів публікації у межах Проекту у грудні 2020 р. було з'ясновано, що ці лікарні на власний розсуд використовували різні моделі впровадження кодування.

В лікарні 1 після проходження базового тренінгу представниками закладу кодування впроваджувалось без суттєвої підтримки та зацікавленості менеджменту та без додаткових заходів щодо навчання персоналу - модель «тренінг + слабкий немотивований менеджмент».

Лікарня 2 стикнулась із ситуацією, коли представники лікарні з поважних причин не відвідали тренінг. Впровадження кодування проводилось за суттєвої підтримки менеджменту, але за відсутністю знань, оволодіння якими представниками лікарні передбачав 
тренінг - модель «відсутність тренінгу + сильний мотивований менеджмент».

В лікарні 3 після участі в базовому тренінгу, за активної підтримки менеджменту було організовано додаткове навчання персоналу 3 подальшим заліком. Менеджмент виказав серйозну зацікавленість у впровадженні проекту, активно спілкувався 3 організаторами проекту (11 запитів на платформі UDRG) та щомісячно проводив обговорення результатів кодування 3 персоналом - модель «тренінг + сильний мотивований менеджмент».

Лікарні не відрізнялись за кількістю пролікованих випадків в закладі - більше 1000 на місяць, рівнем кодування випадків - більше 92\%. Дані збирались в системі УДСГ по кожній із пілотних лікарень після надання ними своїх кодів доступу із дотриманням правил захисту персональної інформації та етичних принципів при проведенні дослідження. В публікації представлені сирі дані без статистичної обробки.

\section{Результати дослідження та їх обговорення}

Впровадження новітніх класифікаторів ставить перш за все питання щодо їх відмінності від класифікаторів, які застосовувались в країні раніше.

Аналіз МКХ-10-АМ (попередня публікація) показав, що він не $\epsilon$ чимось новим, 3 чим ми не зустрічалися. Він базується на МКХ-10, ВООЗ (8), тобто на класифікації 3 якою ми добре знайомі, i яка використовувалась протягом багатьох років.

Іншим класифікатором, який впроваджувався в Україні, був Австралійський класифікатор медичних інтервенцій (АКМI) (5). Цей класифікатор суттєво відрізнявся від чинного до сьогодні Тимчасового галузевого класифікатору медичних процедур (послуг) та хірургічних операцій, затвердженого наказом MO3 України від 14.02.2007 р. № 67 (7).

Класифікатор структуровано за анатомічним принципом (згідно з анатомічною локалізацією органів та систем), а не за принципом хірургічної спеціалізації процедур, як це зроблено в чинному Тимчасовому класифікаторі MO3 України (9). Наскільки це можливо, хірургічні процедури групуються окремо від всіх інших втручань. Отже, АКМІ структуровано в першу чергу за анатомічною локалізацією. В межах кожного класу анатомічна локалізація укладається в порядку «зверху донизу», тобто від голови до стоп (5).

Вторинна вісь, це вісь процедурної типології. Спочатку викладаються найменш інвазивні процедури, а потім - найбільш інвазивні. Використовуються наступні процедурні вісі: обстеження, прикладання, розріз, деструкція, висічення, репозиція, відновлення, реконструкція, ревізія, повторна операція, інші процедури (рисунок 1).

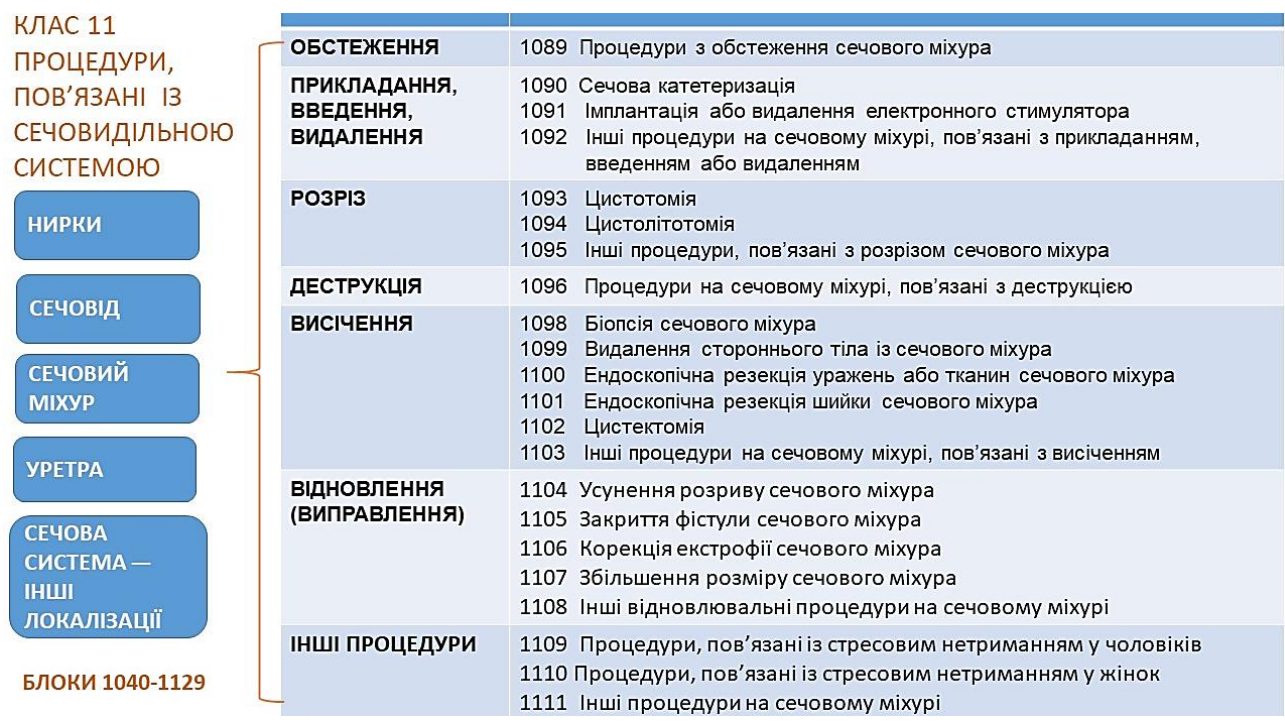

Рис. 1. Вісі анатомічної локалізації та процедурної типології АКМІ (5)

Третій рівень - це вісь блоків. Блоки в Табличному переліку викладені в порядку зростання номеру, що допомагає користувачам знайти потрібний код. Також блоки мають назви, що характеризують включені до них коди. Акушерські процедури мають основну вісь, що базується на циклі вагітності. Наприклад, допологові процедури, процедури, пов'язані з пологами, розродження і т. д. Вторинні вісі стосуються процедурної типології. Так саме, інший формат використовується для процедур радіаційної онкології, інтервенцій не класифікованих в інших рубриках та послуг діагностичної візуалізації (5).
Для коректного кодування багатьох інтервенцій надані зрозумілі детальні пояснення. Така побудова класифікатора спрощує його використання та надає повну інформацію щодо проведених медичних інтервенцій. До переваг застосування AKMI належить перш за все те, що глави класифікатора АКМІ відповідають назвам класів МКХ-10-АМ, останнє забезпечує повну узгодженість термінології, яка використовується в обох цих класифікаторах.

Базові тренінги щодо кодування 3 використанням австралійських класифікаторів було проведено в березні- 
травні 2019 року для більш ніж 700 учасників із 102 пілотних лікарень, обласних та міських управлінь охорони здоров'я, МО3, НСЗУ (6).

Для більш детального розуміння процесу впровадження кодування 3 використанням сучасних класифікаторів на рівні закладів охорони здоров'я, нами проведено аналіз щодо динаміки та якості кодування випадків на прикладі трьох лікарень 3 різним підходом щодо впровадження кодування. Різниця в методології впровадження була встановлена під час моніторингових візитів.
Протягом липня-грудня 2019 року в Лікарні 1 було закодовано 12833 випадків, в Лікарні 2 - 6701 випадків і в лікарні 3 - 11018 випадків. 3 них, загалом, кваліфіковано до різних діагностично-споріднених груп (ДСГ) 79,83\% випадків в Лікарні 1, 86,3\% випадків в Лікарні 2 та 94,7\% випадків в лікарні 3 .

Помилки при групування випадків при кодуванні в системі Українських діагностично-споріднених груп кваліфікували наступним чином (таблиця 1).

Динаміка кількості помилок при кодуванні протягом 6 місяців в трьох лікарнях представлена на рисунку 2.

Таблиця 1. Помилки при групування випадків в системі Українських діагностично-споріднених груп (UDRG - https://www.udrg-system.com)

\begin{tabular}{|c|c|c|}
\hline $\begin{array}{c}\text { Код } \\
\text { помилки }\end{array}$ & Статус групування & Опис \\
\hline 2 & $\begin{array}{l}\text { Діагноз не може бути } \\
\text { використано як основний } \\
\text { діагноз }\end{array}$ & $\begin{array}{l}\text { 1. код знаходиться в діапазоні U50-Y98, що використовується в якості } \\
\text { основного діагнозу } \\
\text { або } \\
\text { 2. встановлений діагноз не може бути основним }\end{array}$ \\
\hline 3 & $\begin{array}{l}\text { Епізод не відповідає } \\
\text { критеріям жодної ДСГ }\end{array}$ & $\begin{array}{l}\text { Основний діагноз не належить до жодної ДСГ або епізод не може бути } \\
\text { віднесено до ДСГ за допомогою алгоритму }\end{array}$ \\
\hline 4 & Недопустимий вік & Вік не можна отримати у допустимому діапазоні \\
\hline 5 & Недопустима стать & Недопустима стать або конфлікт даних про стать $з$ основним діагнозом \\
\hline 7 & $\begin{array}{l}\text { Недопустима вага } \\
\text { при госпіталізації }\end{array}$ & $\begin{array}{l}\text { Якщо вік пацієнта введено або розраховано як } 364 / 365 \text { днів або менше, } \\
\text { значення ваги при госпіталізації є недопустимим і основний діагноз є } \\
\text { діагнозом новонародженого }\end{array}$ \\
\hline
\end{tabular}

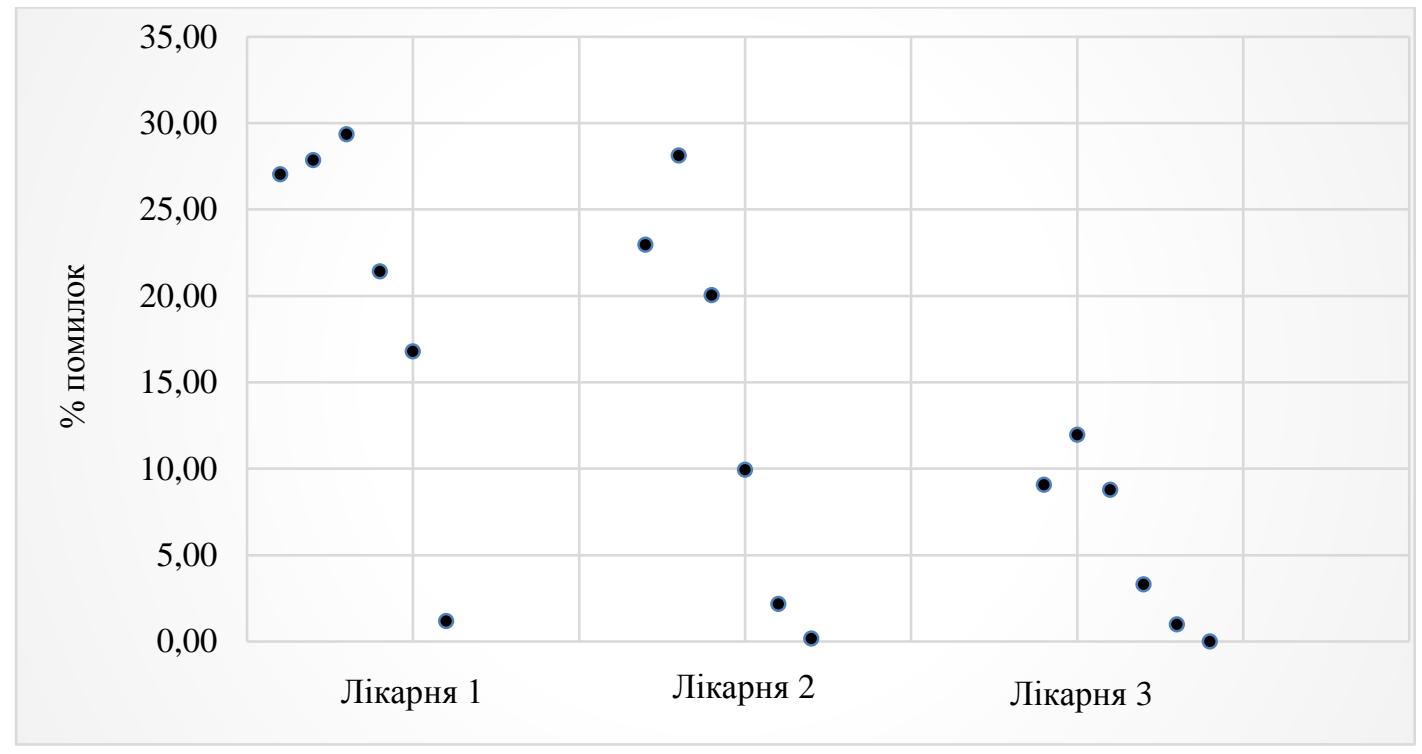

Рис. 2. Динаміка зменшення відсотка помилок при групування випадків в системі UDRG залежно від підходу до впровадження кодування

Досягнення найкращих показників кодування при впровадженні нових класифікаторів та кодуванні випадків в електронній системі потребувало часу. При чому, чим більшою була зацікавленість та активнішою позиція менеджменту, тим швидше та краще відбувався цей процес. Між тим, навіть при участі представників закладу у базовому тренінгу, активній позиції менеджменту 3 підтримкою навчання фахівців, проходило не менше 3 місяців, щоб рівень класифікації випадків до різних ДСГ досягнув 97\%. Тобто, модель впровадження «тренінг + сильний мотивований менеджмент» показала переваги в швидкості зменшення помилок при групування випадків нижче 3\% та досяжності помилок на рівні 0, в порівнянні iз моделями «тренінг + слабкий немотивований 
менеджмент» та «відсутність тренінгу + сильний мотивований менеджмент».

Тобто, активна позиція менеджменту 3 впровадженням тренінгів та заліку для фахівців, подальшим щомісячним моніторингом ситуації виявилась одним із найкращих підходів щодо впровадження кодування в лікувальних закладів в межах проекту.

Аналіз показав, шо серед некласифікованих в ДСГ випадків найчастіше зустрічалась помилка 3 , тобто «Епізод не відповідає критеріям жодної ДСГ» (таблиця 2). Така помилка зазвичай пов'язана із некоректним обранням коду з МКХ-10-АМ.

Загалом, більше ніж 94\% помилок мали відношення до неправильного, з точки зору кількості знаків, обрання коду (замість пя’тизначного - чотиризначного, замість чотиризначного - тризначного). Необхідність правильного обрання коду обговорювалась в попередній публікації.

Більш того, у бататьох випадках інтервенції кодувались лише частково, наприклад, кодувалась операція та не кодувалась анестезія.

Тому в даній публікації ми вирішили представити додаткові алгоритми, щодо пошуку необхідних кодів в AKMI.

\section{Пошук кодів в АКМІ}

Перший крок пошуку кодів в Австралійському класифікаторі медичних інтервенцій - це пошук класу, до якого мають відношення втручання (рисунок 3 ).

\section{Таблиця 2. Відсоток помилок при кодуванні пролікованих випадків} в трьох лікарнях протягом 6 місяців проекту

\begin{tabular}{|l|c|c|c|c|c|c|}
\hline & Помилка 2, \% & Помилка 3, \% & Помилка 5, \% & Помилка 7, \% & \% помилок \\
\hline Лікарня 1 & 0,22 & 19,62 & 0,02 & 0,32 & 20,17 \\
\hline Лікарня 2 & 0,04 & 13,55 & & 0,10 & 13,70 \\
\hline Лікарня 3 & 0,25 & 4,96 & 0,01 & 0,07 & 5,30 \\
\hline
\end{tabular}

\begin{tabular}{|c|c|}
\hline $\begin{array}{l}\text { КЛАС } 1 \text { ПРОЦЕДУРИ НА НЕРВОВІЙ СИСТЕМІ (БЛОКИ 1- } \\
\text { 86) }\end{array}$ & $\begin{array}{l}\text { КЛАС } 11 \text { ПРОЦЕДУРИ, ПОВ'ЯЗАНІ ІЗ СЕЧОВИДІЛЬНОЮ } \\
\text { СИСТЕМОЮ (БЛОКИ 1040-1129) }\end{array}$ \\
\hline $\begin{array}{l}\text { КЛАС } 2 \text { ПРОЦЕДУРИ НА ЕНДОКРИННІЙ СИСТЕМІ } \\
\text { (БЛОКИ 110-129) }\end{array}$ & $\begin{array}{l}\text { КЛАС } 12 \text { ПРОЦЕДУРИ НА ЧОЛОВІЧИХ СТАТЕВИХ } \\
\text { ОРГАНАХ (БЛОКИ 1160-1203) }\end{array}$ \\
\hline $\begin{array}{l}\text { КЛАС } 3 \text { ПРОЦЕДУРИ НА ОЦІ ТА ЙОГО ПРИДАТКАХ } \\
\text { (БЛОКИ 160-256) }\end{array}$ & $\begin{array}{l}\text { КЛАС } 13 \text { ГІНЕКОЛОГІЧНІ ПРОЦЕДУРИ (БЛОКИ } 1240 \text { - } \\
\text { 1299) }\end{array}$ \\
\hline $\begin{array}{l}\text { КЛАС } 4 \text { ПРОЦЕДУРИ НА ВУСІ ТА СОСКОПОДІБНОМУ } \\
\text { ВІДРОСТКУ (БЛОКИ З00-333) }\end{array}$ & КЛАС 14 АКУШЕРСЬКІ ПРОЦЕДУРИ (БЛОКИ 1330-1347) \\
\hline $\begin{array}{l}\text { КЛАС } 5 \text { ПРОЦЕДУРИ НА НОСІ, РОТІ І ГЛОТЦІ (БЛОКИ } \\
\text { 370-422) }\end{array}$ & $\begin{array}{l}\text { КЛАС } 15 \text { ПРОЦЕДУРИ НА СКЕЛЕТНО-М'ЯЗОВІЙ СИСТЕМІ } \\
\text { (БЛОКИ 1360-1580) }\end{array}$ \\
\hline КЛАС 6 СТОМАТОЛОГІЧНІ ПОСЛУГИ (БЛОКИ 450-490) & $\begin{array}{l}\text { КЛАС } 16 \text { ДЕРМАТОЛОГІЧНІ ТА ПЛАСТИЧНІ ПРОЦЕДУРИ } \\
\text { (БЛОКИ 1600-1718) }\end{array}$ \\
\hline $\begin{array}{l}\text { КЛАС } 7 \text { ПРОЦЕДУРИ, ПОВ'ЯЗАНІ З ДИХАЛЬНОЮ } \\
\text { СИСТЕМОЮ (БЛОКИ } 520-572)\end{array}$ & $\begin{array}{l}\text { КЛАС } 17 \text { ПРОЦЕДУРИ НА МОЛОЧНІЙ ЗАЛОЗІ (БЛОКИ } \\
\text { 1740-1759) }\end{array}$ \\
\hline $\begin{array}{l}\text { КЛАС } 8 \text { ПРОЦЕДУРИ, ПОВ'ЯЗАНІ З СЕРЦЕВО- } \\
\text { СУДИННОЮ СИСТЕМОЮ (БЛОКИ 600-777) }\end{array}$ & $\begin{array}{l}\text { КЛАС } 18 \text { ПРОМЕНЕВІ ОНКОЛОГІЧНІ ПРОЦЕДУРИ } \\
\text { (БЛОКИ 1786-1800) }\end{array}$ \\
\hline $\begin{array}{l}\text { КЛАС } 9 \text { ПРОЦЕДУРИ, ПОВ'ЯЗАНІ } 3 \text { КРОВ'Ю ТА } \\
\text { КРОВОТВОРНИМИ ОРГАНАМИ (БЛОКИ 800-817) }\end{array}$ & $\begin{array}{l}\text { КЛАС } 19 \text { ІНТЕРВЕНЦІЇ НЕ КЛАСИФІКОВАНІ В ІНШИХ } \\
\text { РУБРИКАХ (БЛОКИ 1820-1923) }\end{array}$ \\
\hline $\begin{array}{l}\text { КЛАС } 10 \text { ПРОЦЕДУРИ, ПОВ'ЯЗАНІ З СИСТЕМОЮ } \\
\text { ОРГАНІВ ТРАВЛЕННЯ (БЛОКИ 850-1011) }\end{array}$ & $\begin{array}{l}\text { КЛАС } 20 \text { ПОСЛУГИ ДІАГНОСТИЧНОЇ ВІЗУАЛІЗАЦІЇ АКТИ } \\
\text { (БЛОКИ 1940-2016) }\end{array}$ \\
\hline
\end{tabular}

Рис. 3. Класи австралійського класифікатору медичних інтервенцій (АКМІ)

Наступний крок - це пошук номерів блоків, в яких може бути код потрібної інтервенції. Нумерація блоків наскрізна у всьому класифікаторі від 1 до 2016 та кожному класі (Клас 1 - процедури на нервовій системі (блоки 186), Клас 2 - процедури на ендокринній системі (блоки 110-129), Клас 3 - процедури на оці та його придатках (блоки 160-256 ) і т.д.) (рисунок 4).

Для пошуку коду необхідної інтервенції відкриваємо обраний блок та обираємо код потрібного втручання (рисунок 5). Номери на чорному фоні - це номери блоків, вони $€$ недійсними. Код втручання складається 35 цифр, рисочки, та додаткових 2 цифр. Виписуємо номер інтервенції з урахуванням приміток AKMI (включено, виключено). При наявності примітки «кодуйте також, якщо здійснюється» додатково кодуємо необхідну інтервенцію.

Тобто, алгоритм пошуку коду необхідних медичних втручань в АКМІ можна представити наступним чином (рисунок 6). 


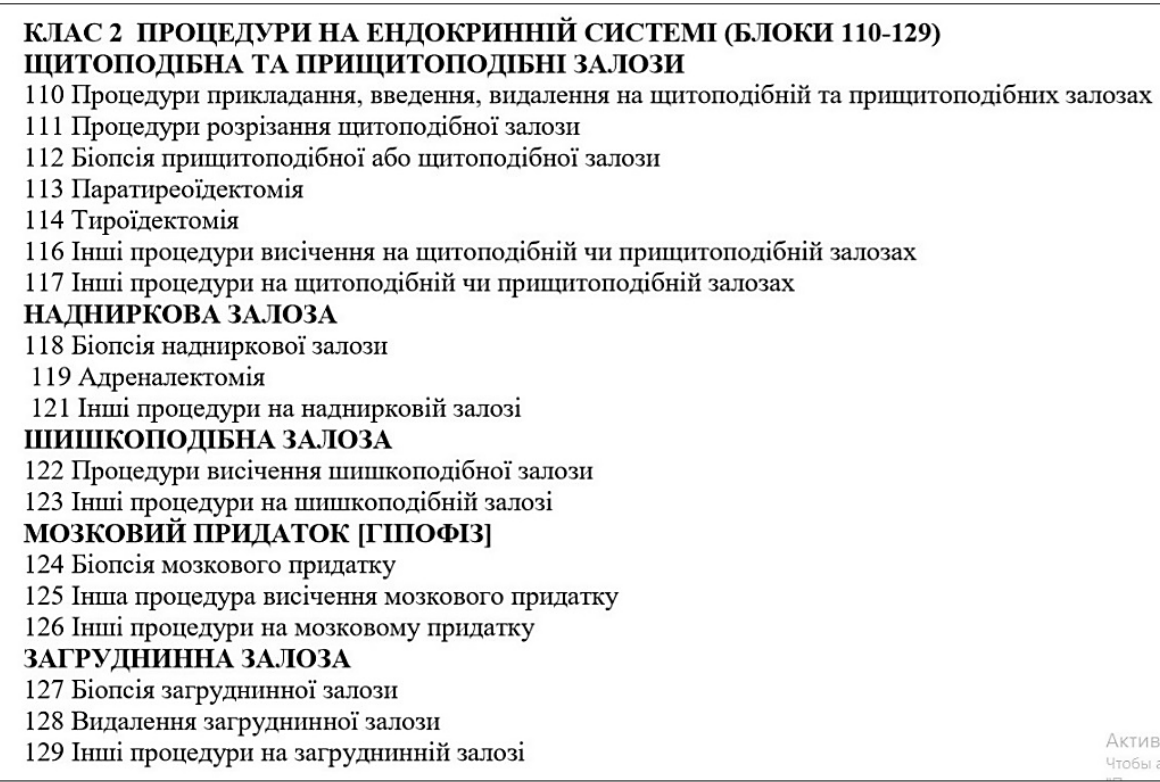

Рис. 4. Пошук номерів блоків АКМІ (5)

\begin{tabular}{|c|c|}
\hline Код А & \\
\hline Номери ю & орному тлі - це номери блоків \\
\hline ВОНИ НЕ & ійсними кодами та НЕ МОЖУТЬ бути присвоєні \\
\hline Наприкла & \\
\hline 1340 & Кесарів розтин \\
\hline $16520-00$ & Плановий класичний кесарів розтин \\
\hline 16520-01 & Екстрений класичний кесарів розтин \\
\hline $16520-02$ & Плановий кесарів розтин у нижньому сегменті матки \\
\hline $16520-03$ & Екстрений кесарів розтин у нижньому сегменті матки \\
\hline
\end{tabular}

Рис. 5. Вибір коду АКМІ (5)

Хірургічні, ендоскопічні інтервенції, анестезія враховуються при присвоєнні коду ДСГ та іiі складності, тому ї завжди потрібно кодувати. При проведенні операції з використанням анестезії, крім коду операції, обов'язково зазначаємо код анестезії. При наявності рядом із кодом трикутника 3 «Номером стандарту» (чотири цифри) обов'язково знайомимось із цим стандартом в «Австралійських стандартах кодування».

У відповідності до стандарту кодування «0016 Загальні вказівки щодо процедур» (Австралійські стандарти кодування, 2017), порядок кодів втручань визначається на основі такої ієрархії (10):

- процедура з лікування основного діагнозу;

- процедура з лікування супутнього діагнозу;

- діагностична процедура/процедура дослідження, що стосується основного діагнозу;

\section{Кодування інтервенцій за АКМI \\ Визначте інтервенцію \\ КЛас? ПЕРЕЛІК КЛАСІВ \\ БЛОК? СПИСОК НОМЕРІВ БЛОКІВ ЗА КЛАСАМИ \\ Інтервенція? ТАБЛИЧНИЙ ПЕРЕЛІК ІНТЕРВЕНЦІЙ}

Рис. 6. Алгоритм кодування медичних втручань

- діагностична процедура/процедура дослідження, що стосується супутнього діагнозу в рамках даного епізоду надання медичної допомоги.

Діагностична процедура під анестезією має кодувати як процедура тільки в тому випадку, якщо це єдина виконувана процедура.

Якщо втручання проводиться під анестезією, коди анестезії слідують за кодами процедури.

Таким чином, правила вибору коду інтервенції, при застосуванні АКМІ роблять неможливим коректний вибір при застосуванні тільки системи Української ДСГ. В ній відсутня інформація щодо включених та виключений понять, та додаткові пояснення щодо кодування (рис. 7).

Так саме, необхідна для коректного вибору коду втручання інформація відсутня в прийнятому в Україні НК 026:2019 - Класифікаторі медичних інтервенцій (2019) (рисунок 8). 
Основний діагноз *

К80.00 - Камінь жовчного міхура з гострим холециститом, без згадки про обструкцію жовчовивідних шляхів

Тип медичної допомоги

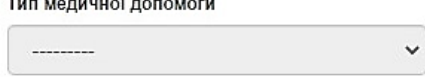

Години механічної вентиляції

2

Вага новонародженого [r]

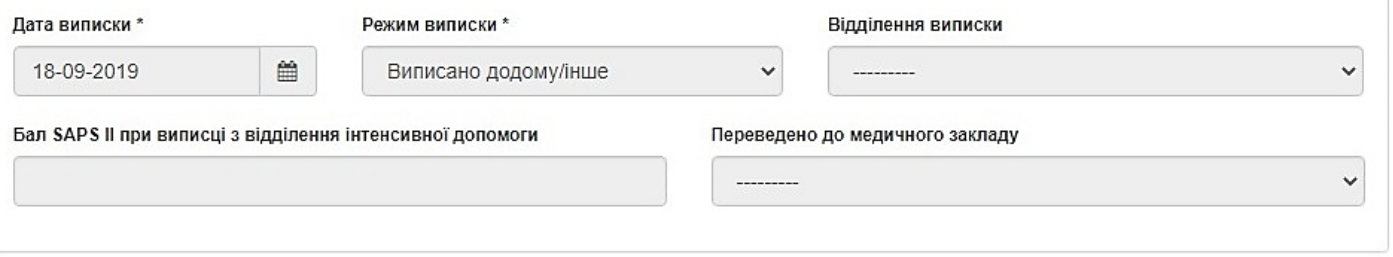

Додаткові діагнози

K74.6 - Інший та неуточнений цироз I

I25.8 - Інші форми хронічної ішемічнс

К29.90 - Гастродуоденіт, неуточнениі
150.9 - Серцева недостатність, неуто

К86.1 - Інший хронічний панкреати

N28.1 - Кіста нирки, набута
Процедури

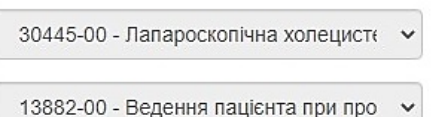

(1)

92514-39 - Загальна анестезія, паціє

Рис. 7. Некоректні джерела для пошуку кодів втручань - система Українських ДСГ (UDRG) (6)

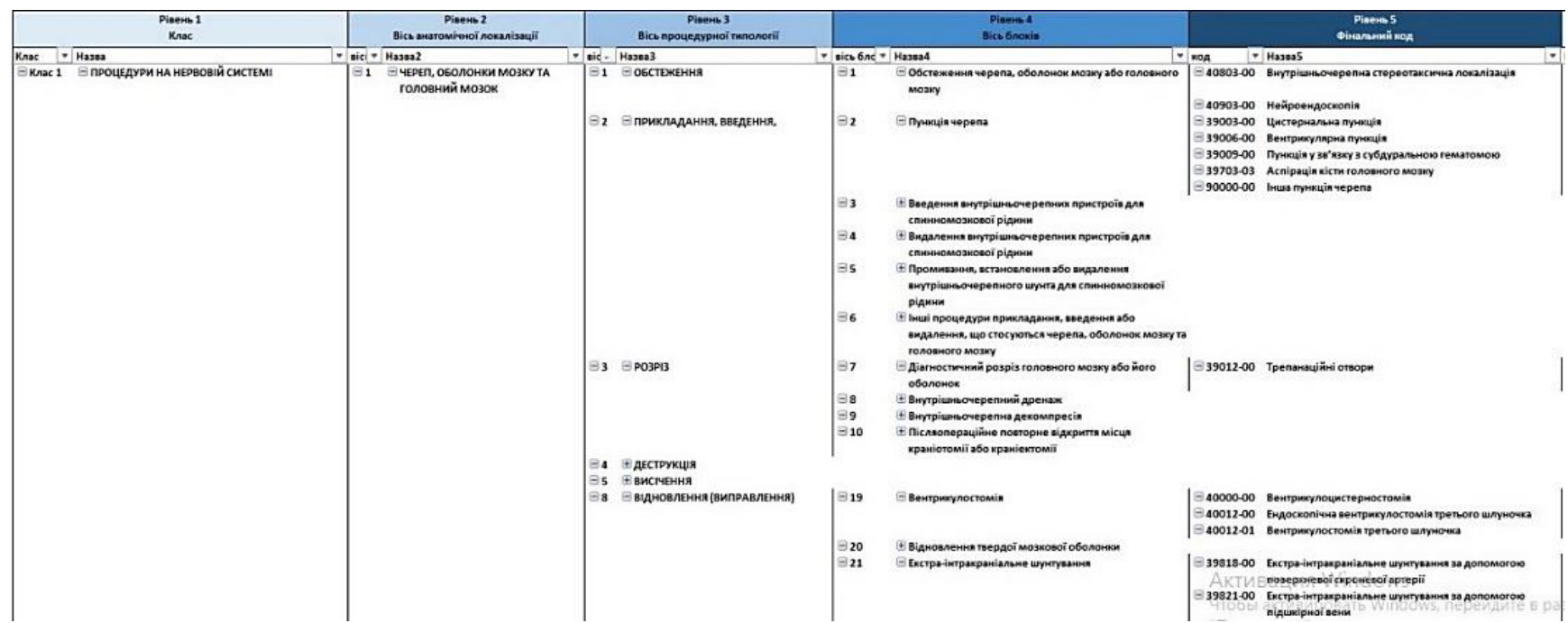

Рис. 8. Некоректні джерела для пошуку кодів втручань - НК 026:2019 - Класифікаторі медичних інтервенцій, 2019 (3)

Тому, перш ніж вводити дані в систему, треба обрати коректні коди (рисунок 9) в табличному переліку класифікатора (5) і тільки після цього вносити їх в систему.

Для ефективної роботи лікарі та статистики мають мати повноцінний класифікатор АКМІ: Табличний перелік.

Більш того, коректне кодування в австралійській системі ДСГ, яка прийнята на сьогодні в Україні, передбачає обов'язкове використання австралійських стандартів кодування (10), які дають вичерпані пояснення щодо кодування як станів, так і втручань. Проблема посідає в тому, що в Австралійській системі формування ДСГ відбувається у відповідності до цих стандартів. I якщо ми починаємо змінювати рекомендації щодо кодування, наприклад інтервенцій, мають бути надані чіткі інструкції щодо зміни правил, і головне, ці зміни мають бути впроваджені в алгоритми формування ДСГ. 


\section{КЛАС 1 ПРОЩЕДУРИ НА НЕРВОВПЙ СИСТЕМІ (БЛОКИ 1-86)}

\section{ЧЕРЕП, ОБОЛОНКИ МОЗКУ ТА ГОЛОВНИЙ МОЗОК}

\section{ОБСТЕЖЕННЯ}

\section{1 Обстеження черепа, оболонок мозку або головного мозку}

40903-00 Нейроендоскопія

$\nabla 0634$

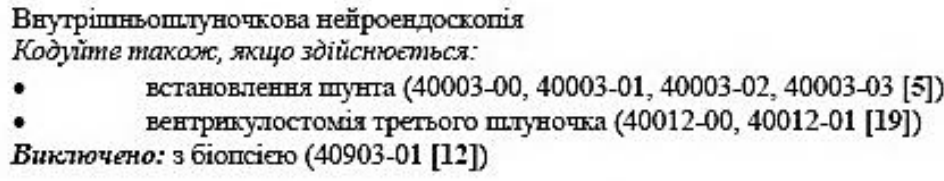

Внутрішньоптуночкова нейроендоскопія

Кодуйте махоже, якцо здійснюетьск:

- $\quad$ встановлення пунта (40003-00, 40003-01, 40003-02, 40003-03 [5])

- вентрикулостомсія третього петунопка (40012-00, 40012-01 [19])

Викиючено: 3 біопсією (40903-01 [12])

40803-00 Внутріпшњотерепна стереотакснчна локалізація $\nabla 0629$

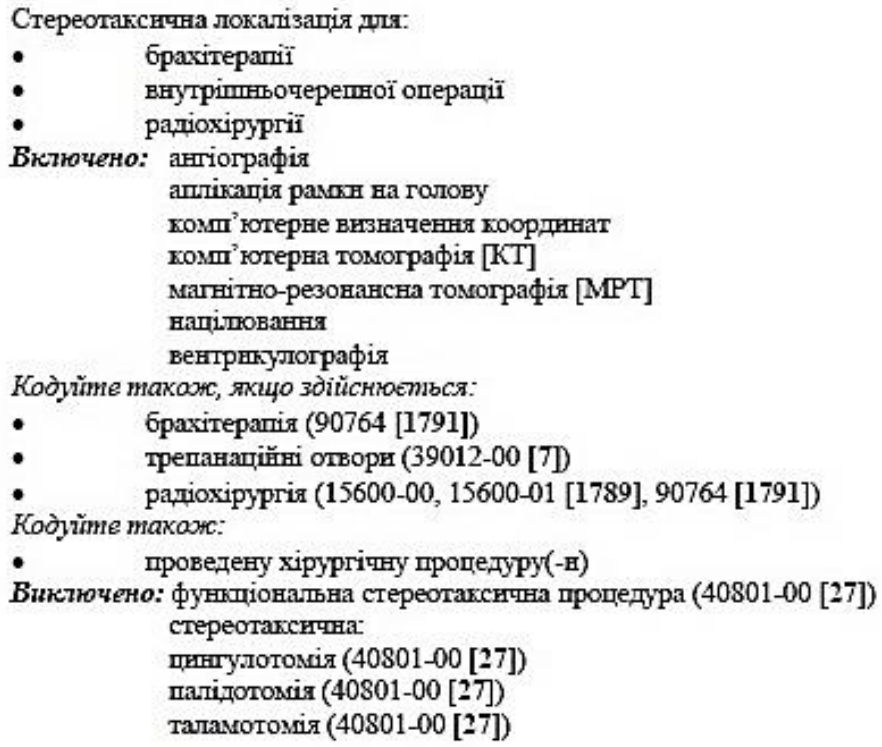

Рис. 9. Коректне джерело для вибору коду втручань - Австралійський класифікатор медичних інтервенцій (АКМІ) (5)

\section{Перспективи подальших досліджень}

Подальші дослідження можуть включати вплив впровадження австралійських класифікаторів на показники статистичної звітності на рівні закладу охорони здоров’я, а також на рівні країни.

\section{Висновки}

Проведене дослідження показало, що запропонований класифікатор медичних інтервенцій суттєво відрізняється від Тимчасового галузевого класифікатору медичних процедур (послуг) та хірургічних операцій, затвердженого наказом MO3 України від 14.02.2007 p. № 67. Між тим, Австралійський класифікатор медичних інтервенцій характеризується незрівнянно вищою якістю і логікою організації, що робить його більш зрозумілим і простим у використанні.

При впровадженні АКМІ в країні треба додатково зосередитись на алгоритмі пошуку необхідних кодів. Для кодування інтервенцій в пролікованих випадках не можна обмежитись запропонованим класифікатоом НК 026:2019. Всі три перекладені австралійські класифікатори в повному обсязі мають бути доступними для фахівців, задіяних в процесі кодування.

Активна позиція менеджменту, впровадження тренінгів для кожного фахівця, щомісячний моніторинг кодування $\epsilon$ одним із найкращих підходів щодо впровадження новітніх класифікаторів та електронної реєстрації пролікованих в стаціонарі випадків в межах впровадження нової моделі оплати діяльності стаціонарів, що базується на оплаті за пролікований випадок. 


\section{Лiтература/References}

1. Наказ Мінекономіки від 13 грудня 2019 року №677 Про затвердження національних класифікаторів. (Nakazu Minekonomiky vid 13 hrudnia 2019 roku №677 Pro zatverdzhennia natsionalnykh klasyfikatoriv).

2. Класифікатор хвороб та споріднених проблем охорони здоров'я НК 025:2019, Київ, МОЗ України, 2019 р. (Klasyfikator khvorob ta sporidnenykh problem okhorony zdorovia NK 025:2019, Kyiv, MOZ Ukrainy, 2019 r.).

3. Класифікатор медичних інтервенцій НК 026:2019, Київ, МОЗ України, 2019 p. (Klasyfikator medychnykh interventsii NK 026:2019, Kyiv, MOZ Ukrainy, 2019 r.).

4. The International Statistical Classification of Diseases and Related Health Problems, Australian Modification (ICD10-AM). Tabular List, Tenth Revision, 1 July 2017. Independent Hospital Pricing Authority, 2017 (Міжнародна статистична класифікація хвороб та споріднених проблем охорони здоров'я. Десятий перегляд, Австралійська модифікація: Табличний перелік. Десяте видання 1 липня 2017 р. НУКЦПМУ Незалежне управління по контролю цінової політики медичних установ https://academy.nszu.gov.ua/ ) (Mizhnarodna statystychna klasyfikatsiia khvorob ta sporidnenykh problem okhorony zdorovia. Desiatyi perehliad, Avstraliiska modyfikatsiia: Tablychnyi perelik. Desiate vydannia 1 lypnia 2017 r. NUKTsPMU Nezalezhne upravlinnia po kontroliu tsinovoi polityky medychnykh ustanov https://academy.nszu.gov.ua/).

5. Australian Classification of Health Interventions. ACHI. Tabular List. Tenth Edition, 1 July 2017. Independent Hospital Pricing Authority, 2017 (Австралійський класифікатор медичних інтервенцій (АКМI): Табличний перелік інтервенцій. Десяте видання 1 липня 2017 р. НУКЦПМУ Незалежне управління по контролю цінової політики медичних установ https://academy.nszu.gov.ua/ ) (Avstraliiskyi klasyfikator medychnykh interventsii (AKMI): Tablychnyi perelik interventsii. Desiate vydannia 1 lypnia 2017 r. NUKTsPMU Nezalezhne upravlinnia po kontroliu tsinovoi polityky medychnykh ustanov https://academy.nszu.gov.ua/).

6. Перспективи впровадження австралійської системи діагностично-споріднених груп в Україні (презентація, Кароліна Каланж, 8 березня 2019) https://wb.moz.gov.ua/en/struktura-proektu/komponent-3_-upravlinnia-proektom/ monitoryng-i-otsinka/novyny-ta-podii.html?action=view\&id=1483 (Perspektyvy vprovadzhennia avstraliiskoi systemy diahnostychno-sporidnenykh hrup v Ukraini (prezentatsiia, Karolina Kalanzh, 8 bereznia 2019 https://wb.moz.gov.ua/en/ struktura-proektu/komponent-3_-upravlinnia-proektom/monitoryng-i-otsinka/novyny-ta-podii.html?action=view\&id=1483).

7. Тимчасовий галузевий класифікатор медичних процедур (послуг) та хірургічних операцій, затверджений наказом МОЗ України від 14.02.2007 р. № 67. (Tymchasovyi haluzevyi klasyfikator medychnykh protsedur (posluh) ta khirurhichnykh operatsii, zatverdzhenyi nakazom MOZ Ukrainy vid 14.02.2007 r. № 67).

8. Міжнародна статистична класифікація хвороб та споріднених проблем охорони здоров'я: Десятий перегляд: МКХ-10 [Текст] : [Пер. з англ.] / ВООЗ, Укр. ін-т громад.здоров'я. - К. : Здоров’я, 1998. (Mizhnarodna statystychna klasyfikatsiia khvorob ta sporidnenykh problem okhorony zdorovia: Desiatyi perehliad: MKKh-10 [Tekst] : [Per. z anhl.] / VOOZ, Ukr. in-t hromad.zdorovia. - K. : Zdorovia, 1998).

9. Що таке Австралійська система ДСГ та чому вона необхідна Україні? (презентація, В. Рудий, К. Россол, С. Дяченко, I. Могілевкіна, С. Сіромаха, М. Соколов, 23 січня 2018) https://wb.moz.gov.ua/struktura-proektu/komponent2_-tsentralni-komponenty/dsg/seminary-ta-robochi-narady.html?action=view\&id=167 (Shcho take Avstraliiska systema DSH ta chomu vona neobkhidna Ukraini? (prezentatsiia, V. Rudyi, K. Rossol, S. Diachenko, I. Mogilevkina, S. Siromakha, M. Sokolov, 23 sichnia 2018).

10. Australian Coding Standards. ACS. Tenth Edition, 1 July 2017. Independent Hospital Pricing Authority, 2017 (Австалійські страндарти кодування для МКХ-10-АМ та АКМІ. Десяте видання 1 липня 2017 р. НУКЦПМУ Незалежне управління по контролю цінової політики медичних установ https://academy.nszu.gov.ua/) (Avstaliiski strandarty koduvannia dlia MKKh-10-AM ta AKMI. Desiate vydannia 1 lypnia 2017 r. NUKTsPMU Nezalezhne upravlinnia po kontroliu tsinovoi polityky medychnykh ustanov https://academy.nszu.gov.ua/).

Дата надходження рукопису до редакції: 03.07.2020 p.

Мета - проаналізувати відмінності новітнього класифікатора медичних інтервенцій від існуючого в Україні, помилки при групування пролікованих випадків, визначити найбільш ефективну, з точки зору коректності кодування, модель впровадження кодування за австралійським класифікаторами в межах пілотного проекту.

Матеріали та методи. Австралійський класифікатор медичних інтервенцій (АКМI, 2017) та НК 026:2019 «Класифікатор медичних інтервенцій».

30552 випадки, внесених до електронної системи Українських діагностично-споріднених груп (УДСГ) протягом липня-грудня 2019 року в 3 пілотних лікарнях з різним підходом до впровадження кодування.

Результати. Модель впровадження кодування «тренінг + сильний мотивований менеджмент» показала переваги в швидкості зменшення помилок при групування випадків нижче $3 \%$ та досяжності помилок на рівні 0 , в порівнянні із моделями «тренінг + слабкий немотивований менеджмент» та «відсутність тренінгу + сильний мотивований менеджмент». Більше ніж 94\% помилок при групування випадків в системі УДСГ мали відношення до неправильного, 3 точки зору кількості знаків, обрання коду. 
Висновки. Враховуючи суттєві відмінності АКМІ від існуючого в країні класифікатора медичних процедур треба додатково зосередитись на алгоритмі пошуку необхідних кодів інтервенцій в класифікаторі.

Критичним є доступність перекладеного класифікатору АКМІ та Австралійських стандартів кодування в повному обсязі для фахівців, задіяних в процесі кодування. Ні в якому кодування не можна обмежити застосуванням запропонованого в країні класифікатора НК 026:2019.

Активна позиція менеджменту, заохочення до тренінгів всіх фахівців, щомісячний моніторинг кодування, тобто, модель «тренінг + сильний мотивований менеджмент»- один із найкращих підходів щодо впровадження новітніх класифікаторів та електронної реєстрації пролікованих в стаціонарі випадків.

Ключові слова: класифікатори австралійської системи ДСГ, впровадження в Україні, модель впровадження.

Цель - проанализировать различия нового классификатора медицинских интервенций от существующего в Украине, ошибки при группировке пролеченных случаев, определить наиболее эффективную, с точки зрения корректности кодировки, модель внедрения кодирования с использованием австралийских классификатороа в рамках пилотного проекта.

Материалы и методы. Австралийский классификатор медицинских интервенций (АКМИ, 2017) и НК 026:2019 - «Классификатор медицинских интервенций».

30552 случая, внесенные в электронную систему Украинских диагностически-родственных групп (УДРГ) в течение июля-декабря 2019 году в 3 пилотных больницах с разным подходом к внедрению кодирования.

Результаты. Модель внедрения кодирования «тренинг + сильный мотивированный менеджмент» показала преимущества в скорости уменьшения ошибок при группировке случаев ниже $3 \%$ и достижении ошибок на уровне 0 , по сравнению с моделями «тренинг + слабый немотивированный менеджмент» и «отсутствие тренинга + сильный мотивированный менеджмент». Более 94\% ошибок при группировке случаев в системе УДРГ имели отношение к неправильному, с точки зрения количества знаков, выбору кода.

Выводы. Учитывая существенные различия АКМИ от существующего в стране классификатора медицинских процедур необходимо дополнительно сосредоточиться на алгоритме поиска кодов интервенций в классификаторе.

Критическим является доступность переведенного классификатора АКМИ и Австралийских стандартов кодирования в полном объеме для специалистов, задействованных в процессе кодирования. Ни в коем случае кодирования нельзя ограничить применением предложенного в стране классификатора НК 026:2019.

Активная позиция менеджмента, поощрение участия в тренингах всех специалистов, ежемесячный мониторинг кодирования, то есть, модель «тренинг + сильный мотивированный менеджмент» - один из лучших подходов к внедрению новейших классификаторов и электронной регистрации пролеченных в стационаре случаев.

Ключевые слова: классификаторы австралийской системы ДРГ, внедрение в Украине, модель внедрения.

The purpose - to analyze the differences between the new classifier of medical interventions from the existing one in Ukraine, errors in grouping of inpatient cases, determine the most effective, in terms of coding correctness, model of coding implementation according to Australian classifiers within the pilot Project.

Materials and methods. Australian Classifier of Medical Interventions (ACMI, 2017) and NC 026:2019 - "Classifier of Medical Interventions".

30552 cases entered into the electronic system of the Ukrainian diagnostic-related groups (UDRG) during July-December 2019 in 3 pilot hospitals with different approaches to coding implementation.

Results. "The training + strong motivated management" coding implementation model has showed advantages in reducing error rates when grouping cases below 3\% and achievement of error rates at 0 level, compared to the "training + weak unmotivated management" and "lack of training + strong motivated management" models. More than 94\% of the errors in grouping cases in the UDRG system were related to incorrect, in terms of number of characters, choice of the code.

Conclusions. Given the significant differences between ACMI and the country's existing classifier of medical procedures, it is necessary to additionally focus on the algorithm for finding the necessary intervention codes in the classifier.

The availability of the full translated version of ACMI classifier and Australian coding standards for professionals involved in the coding process is critical. In no case, when coding, one should be limited to the NC 026:2019 version of the classifier proposed in the country.

An active management position, encouragement of trainings of all specialists, monthly monitoring of coding, ie, the model "training + strong motivated management" - is one of the best approaches to the introduction of the newest classifiers and electronic registration of inpatient cases.

Key words: Classifiers of Australian DRG system, implementation in Ukraine, implementational model.

Конфлікт інтересів: відсутній.

Conflicts of interest: authors have no conflicts of interest to declare. 
Примітка: всі автори публікації до 30.06 .2020 р. були консультантами проекту «Пілотне впровадження системи ДСГ (на основі австралійської системи ДСГ) на рівні МО3 та вибраних медичних закладів (навчання, програмне забезпечення тощо)». Представлене дослідження виходить за межі проектного договору.

\section{Відомості про авторів}

Могілевкіна Ірина Олександрівна - д.мед.наук, професор, професор ННЦ НПО ІПО Національний медичний університет ім.О.О. Богомольця; 03057 м. Київ, просп. Перемоги, 34.

+380 (50) 473-90-59, imogilevkina@gmail.com, ORCID ID 0000-0001-8426-3841.

Дорохіна Анна Миколаївна - к.мед.наук, заступник головного лікаря по медичній частині ДУ «ННЦ «Інститут кардіології ім. акад. М.Д. Стражеска» НАМН України; 03680 м. Київ, вул. Народного Ополчення, 5.

+380 (97) 460-50-59, annadoroxina@ukr.net, ORCID ID 0000-0002-6853-8662.

Сіромаха Сергій Олегович - к.мед.наук, головний лікар дУ «Національний інститут серцево-судинної хірургії ім. М.М. Амосова НАМН України»; 03038 м. Київ, вул. Амосова, 6. Національний медичний університет ім. О.О. Богомольця.

+380 (67) 997-30-25, newsersir@gmail.com, ORCID ID 0000-0002-7031-5732. 